\title{
The effect of distension pressure on endothelial injury and vasodilatation response in saphenous vein grafts: conversion of a bypass graft to a dead pipe
}

\author{
Selami Gurkan ${ }^{1}$, Ozcan Gur ${ }^{1}$, Volkan Yuksel ${ }^{2}$, Ebru Tastekin ${ }^{3}$, Serhat Huseyin ${ }^{2}$, \\ Demet Ozkaramanli Gur ${ }^{4}$, Suat Canbaz ${ }^{2}$ \\ ${ }^{1}$ Department of Cardiovascular Surgery, Namik Kemal University, Tekirdag, Turkey \\ 2Department of Cardiovascular Surgery, Trakya University Hospital, Edirne, Turkey \\ ${ }^{3}$ Department of Pathology, Trakya University Hospital, Edirne, Turkey \\ ${ }^{4}$ Department of Cardiology, Tekirdag State Hospital, Tekirdag, Turkey \\ Kardiochirurgia i Torakochirurgia Polska 2014; 11 (2): 119-125
}

\begin{abstract}
Introduction: Endothelial damage caused by high pressure applied for spasm relaxation during graft preparation is one of the most plausible theories explaining early graft failure.

Aim of the study: We aimed to demonstrate the extent of endothelial damage in saphenous vein grafts distended to different pressure levels by using immunohistochemical methods and in vitro tissue baths.

Material and methods: Saphenous vein grafts (SVGs) of 25 patients who underwent isolated elective CABG surgery were used in this study. By using a specific mechanism, SVGs were distended to five different pressure levels for two minutes: $0 \mathrm{mmHg}, 50 \mathrm{mmHg}, 100 \mathrm{mmHg}, 200 \mathrm{mmHg}, 300 \mathrm{mmHg}$. In vitro tissue baths and immunohistochemical examinations were performed.

Results: None of the grafts distended to $300 \mathrm{mmHg}$ pressure were functional in the tissue bath system. The relaxation response to carbachol of SVGs distended to 0,50, 100 and $200 \mathrm{mmHg}$ was $97.87 \pm 4.47 \%, 98.52 \pm 3.95 \%, 93.78 \pm 3.64 \%$, and $30.87 \pm 4.11 \%$, respectively. There were no statistically significant differences in terms of relaxation responses between samples distended to 0,50 , and $100 \mathrm{mmHg}(p=0.490)$. The relaxation response of samples distended to $200 \mathrm{mmHg}$ was significantly decreased $(p=0.021)$. The endothelia of samples distended to $0 \mathrm{mmHg}$ were almost intact in CD31 staining. Endothelial cell loss occurred at all tested distension pressures at different degrees.

Conclusion: In vitro and immunohistochemical studies revealed that distending an SVG used for coronary artery bypass grafting with pressures of $100 \mathrm{mmHg}$ or less results in less endothelial damage and increases graft patency.
\end{abstract}

Key words: saphenous vein, bypass, endothelial injury, vasodilatation.

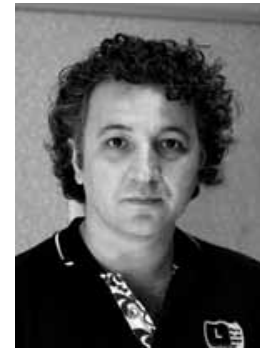

\section{Streszczenie}

Wstęp: Uszkodzenie śródbłonka spowodowane przez wysokie ciśnienia stosowane do relaksacji skurczów przy preparowaniu przeszczepu jest jedną z najbardziej prawdopodobnych teorii wyjaśniających wczesną niewydolność przeszczepu.

Cel pracy: Zademonstrowanie uszkodzenia śródbłonka w przeszczepach żyły odpiszczelowej, na które wywierano ciśnienie o różnej wysokości przy użyciu metod immunohistochemicznych i łaźni tkankowych (tissue bath) przeprowadzanych in vitro.

Materiat i metody: Badano przeszczepy żył odpiszczelowych (saphenous vein graft - SVG) 25 pacjentów, którzy przeszli izolowane elektywne pomostowanie aortalno-wieńcowe (coronary artery bypass grafting - (ABG). Przy użyciu swoistego mechanizmu oddziaływano na SVG przez 2 minuty ciśnieniem o 5 różnych wartościach: $0 \mathrm{~mm} \mathrm{Hg}, 50 \mathrm{~mm} \mathrm{Hg}, 100 \mathrm{~mm} \mathrm{Hg}$, $200 \mathrm{~mm} \mathrm{Hg}$ oraz $300 \mathrm{~mm} \mathrm{Hg}$. Zastosowano łaźnie tkankowe in vitro oraz przeprowadzono badania immunohistochemiczne. Wyniki: Żaden z przeszczepów, na które oddziaływano ciśnieniem $300 \mathrm{~mm} \mathrm{Hg}$, nie funkcjonował w systemie łaźni tkankowej. Odpowiedź rozkurczowa SVG, na które oddziaływano ciśnieniem 0, 50, 100 i $200 \mathrm{~mm} \mathrm{Hg}$, na karbachol wynosiła odpowiednio $97,87 \pm 4,47 \%, 98,52 \pm 3,95 \%, 93,78 \pm 3,64 \%$ oraz $30,87 \pm 4,11 \%$. Nie wystąpiły żadne istotne statystycznie różnice w zakresie odpowiedzi rozkurczowej pomiędzy próbkami, na które oddziaływano ciśnieniem 0, 50 i 100 mm Hg $(p=0,490)$. Odpowiedź rozkurczowa próbek, na które oddziaływano ciśnieniem $200 \mathrm{~mm} \mathrm{Hg}$, była znacząco zmniejszona ( $p=0,021)$. W przypadku śródbłonka próbek, na które oddziaływano ciśnieniem $0 \mathrm{~mm} \mathrm{Hg}$, barwienie CD31 ukazało niemalże nienaruszoną tkankę. Utrata komórek śródbłonka następowała przy wszystkich testowanych ciśnieniach w różnym stopniu. 


\section{Introduction}

The saphenous vein was first used as a graft by Sabiston for coronary artery disease in 1963 [1]. Since Favaloro's interpositioning of the saphenous vein between the right coronary artery and the aorta in 1968, it has been widely used as an aortocoronary bypass conduit [2].

In the mid 1980s, two studies revealed the superior tenyear patency rates of internal thoracic artery grafts (ITA) to the saphenous vein graft (SVG) [3, 4]. Despite increased attention to arterial grafts, SVGs are still the most commonly used graft type in coronary artery bypass grafting surgery (CABG) due to their wide diameter, ease of preparation and length.

Postoperative early term occlusion rates of SVG are reported as $15-26 \%$ [5]. For late term, 10-year patency rates are reported as $50 \%$ and atherosclerotic changes were evident in the patent grafts [6]. There are many theories for failure of saphenous veins. The theory accepted by the majority of surgeons suggests that endothelia and media damage caused by high pressure for relaxation of spasm during preparation of the graft is responsible for graft occlusion [7]. There are many studies on methods for reducing endothelial damage such as keeping grafts in vasodilator agents and preparing grafts with the "no-touch" technique $[8,9]$. Viaro et al. reported that endothelial-derived nitric oxide synthase (eNOS) levels are decreased in grafts distended with high pressure by using immunohistochemical methods [10].

\section{Aim of the study}

We aimed to demonstrate endothelial damage in saphenous vein grafts distended to different pressure levels by using immunohistochemical methods. Also we aimed to detect whether the relaxation response originating from endothelia is altered by this damage in vitro in tissue baths.

\section{Material and methods \\ Patient selection}

After obtaining informed consent and the Ethical Committee's approval, SVGs of 25 patients [ 19 male, 6 female, mean age: $59.52 \pm 9.09$ (44-75 years)] who underwent isolated elective CABG surgery at our institution between May 2013 and October 2013 were used in this study. By using a specific mechanism, SVGs were distended to five different pressure levels for two minutes: $0 \mathrm{mmHg}, 50 \mathrm{mmHg}$, $100 \mathrm{mmHg}, 200 \mathrm{mmHg}, 300 \mathrm{mmHg}$. Eighty SVGs (16 different SVG samples of each pressure group) were examined
Wnioski: Na podstawie badań in vitro i immunohistochemicznych stwierdzono, że oddziaływanie na SVG, których używa się do CABG, ciśnieniem 100 mm Hg lub niższym skutkuje mniejszym uszkodzeniem tkanki i zwiększa drożność przeszczepu.

Słowa kluczowe: żyła odpiszczelowa, pomostowanie, uszkodzenie śródbłonka, wazodylatacja.

in vitro in tissue baths. Afterwards immunohistochemical examination was performed in the pathology laboratory.

Patients with a history of deep vein thrombosis, venous insufficiency, venotonic drug usage, peripheral arterial disease or diabetes mellitus and patients with macroscopic varicosities were excluded from this study.

\section{Graft harvesting and experimental design}

All grafts were harvested by the same surgeon using routine complete skin incision with scissors. The distal end of the vein was cannulated at ankle level, all branches were ligated and the graft was prepared without a pedicle. No vasodilator agent was used while harvesting grafts. After harvesting approximately $10 \mathrm{~cm}$ of graft, the proximal end was occluded with a vascular clamp. The SVG was distended with previously prepared heparinized saline solution (5000 units of unfractionated heparin was diluted in $1000 \mathrm{~mL}$ of $0.9 \% \mathrm{NaCl}$ solution) with the help of a pressure infusion cuff with a sphygmomanometer (ERKA D-83646, Berlin, Germany) for 2 minutes. Afterwards, $2-3 \mathrm{~cm}$ of graft was prepared for the tissue bath system and a $1 \mathrm{~cm}$ segment was resected for pathologic examination. Clamped parts of the vein were not used for the study.

\section{Tissue bath system}

The saphenous vein segments were transferred to the vascular laboratory in $4^{\circ} \mathrm{C}$ Krebs solution (composition: $122 \mathrm{mmol} / \mathrm{L}$ sodium chloride [ $\mathrm{NaCl}], 5 \mathrm{mmol} / \mathrm{L}$ potassium chloride $[\mathrm{KCl}], 1.25 \mathrm{mmol} / \mathrm{L}$ calcium chloride $\left[\mathrm{CaCl}_{2}\right]$, $25 \mathrm{mmol} / \mathrm{L}$ sodium hydrogen carbonate $\left[\mathrm{NaHCO}_{3}\right], 1.2 \mathrm{mmol} / \mathrm{L}$ magnesium sulfate $\left[\mathrm{MgSO}_{4}\right], 1.0 \mathrm{mmol} / \mathrm{L}$ monopotassium phosphate $\left[\mathrm{KH}_{2} \mathrm{PO}_{4}\right]$, and $11.5 \mathrm{mmol} / \mathrm{L}$ glucose) that was continuously aerated with $95 \%$ oxygen $\left(\mathrm{O}_{2}\right)$ and $5 \%$ carbon dioxide $\left(\mathrm{CO}_{2}\right)$. Each graft was sliced into rings of $3 \mathrm{~mm}$ width. The vascular rings were suspended in the classical tissue bath system via steel hooks. Active tension of 1 to $4 \mathrm{~g}$ was applied to all of the samples. The vascular rings were suspended under this tension for a minimum of 60 minutes. The samples were kept alive by $37^{\circ} \mathrm{C}$ oxygenated Krebs solution baths every 20 minutes. In order to measure the relaxation response, the samples were exposed to phenylephrine (Sigma) $\left(10^{-6} \mathrm{M}\right)$ first for submaximal constriction. Afterwards, carbachol (Sigma-Aldrich ${ }^{\circledR}$ ) was used to induce nitric oxide (NO)-mediated vasodilatation. While the phenylephrine was still in the environment, carbachol was administered to the tissue bath every two minutes starting at a concentration of $10^{-8} \mathrm{M}$ and increasing in logarithmic increments to a concentration of $10^{-4} \mathrm{M}$. The vasodilatation 
response curves were obtained and recorded as described above. The data were transferred to the computer with the help of the Transducer Acquisition System (MAY IOBS 99, FDT 05 Ankara-Turkey) and stored with the MAY-MASTER MP36 analysis program.

\section{Immunohistochemical evaluation}

SVG segments were fixed in $10 \%$ formaldehyde for 12 hours and than paraffin-embedded. Three cross-sectional slices were prepared from different parts of each SVG segment. The first was stained with hematoxylin and eosin and the second with CD31 antibody. CD31-immunostaining was performed to evaluate saphenous vein endothelial cells, as CD31 is a specific marker of endothelial cells, as described by Stigler et al. [11]. Antigen retrieval was performed for 30 min at $98^{\circ} \mathrm{C}$. CD31 antibody (Thermo Scientific ${ }^{\text {TM }}$ CD31/ PECAM-1, Rabbit Polyclonal Antibody) was added for $60 \mathrm{~min}$. Staining and antibody detection were performed according to the kit protocol (Thermo Scientific). Microscopically, CD31+ endothelial cells on the intimal surface were evaluated. The ratio of CD31+ endothelial cell surface to the total intimal surface of the cross-section (CD31+ endothelial cell surface and de-endothelialized tunica intima) demonstrated the percentage of endothelial cell coverage. The percentage of endothelial cell loss was noted. Endothelial cell loss results for a distinct distension pressure are expressed as the median value of three measurements in different parts of the SVG segment. Evaluation of immunohistochemistry was performed by an experienced pathologist (without prior knowledge of the features of slides).

\section{Statistical analysis}

The program GraphPad Prism 6 Version Demo was used for analyzing tissue bath data. Concentration-response graphs were obtained by using statistical properties of the same program. Non-linear regression analysis (variable slope) and one-way ANOVA analysis were preferred for graphics. Intra-group analyses of groups were performed by using the $t$ test.

Standard deviation, median and minimum-maximum values were used for descriptive statistics of immunohistochemical data. Kolmogorov-Smirnov test was used for distribution of variables. Paired samples $t$ test was used for quantified data. Data were analyzed using the Statistical Package for Social Sciences 21.0 for Windows (SPSS Inc., Chicago, Illinois, USA). The results were assessed within a $95 \%$ confidence interval and at a level of $p<0.05$ significance.

\section{Results}

Between May 2013 and October 2013, 25 patients were included in this study.

\section{Tissue bath system}

Phenylephrine (10-6 M concentration) was routinely administered to grafts for achieving sub-maximal contrac- tion. Afterwards, carbachol was administered in a cumulatively increasing manner from $10^{-8}$ to $10^{-4} \mathrm{M}$ concentration and nitric oxide mediated dose-relaxation graphics were obtained separately (Fig. 1).

None of the grafts distended to $300 \mathrm{mmHg}$ pressure were functional in the tissue bath system. Statistical analysis was not possible because neither a contraction nor a relaxation response was achieved.

Relaxation responses to carbachol of SVGs distended to $0,50,100$ and $200 \mathrm{mmHg}$ were $97.87 \pm 4.47 \%, 98.52 \pm$ $3.95 \%, 93.78 \pm 3.64 \%$ and $30.87 \pm 4.11 \%$, respectively. Log EC50 values were determined as $-5.932,-6.016,-6.132$, -7.434 , respectively. There were no statistically significant differences for relaxation responses of samples distended to 0,50 and $100 \mathrm{mmHg}(p=0.490)$. Relaxation responses of samples distended to $200 \mathrm{mmHg}$ were significantly decreased ( $p=0.021$ ) (Fig. 2).

\section{Endothelial cell loss of SVGs via CD31 immunostaining}

Diameters of SVGs distended to 200 and $300 \mathrm{mmHg}$ were significantly increased in macroscopic evaluation (Fig. 3). Endothelia of samples distended to $0 \mathrm{mmHg}$ were almost intact with CD31 staining. De-endothelialized areas were similar in groups distended to 50 and $100 \mathrm{mmHg}$. In $200 \mathrm{mmHg}$ group these areas were significantly increased. There was a near total loss of endothelial cells in the group distended to $300 \mathrm{mmHg}$ (Fig. 4). Endothelial cell loss occurred at all tested distension pressures at different degrees. The extent of acute endothelial cell loss increased with increasing pressure magnitude. At $0 \mathrm{mmHg}$ the mean endothelial cell loss was $0.8 \pm 1.6 \%$ (range: $0-5 \%, p=$ NS or baseline), at $50 \mathrm{mmHg} 34.5 \pm 10.8 \%$ (range: $20-55 \%, p<0.001$ ), at $100 \mathrm{mmHg} 50.0 \pm 7.1 \%$ (range: $40-60 \%, p<0.001$ ), at $200 \mathrm{mmHg} 75.5 \pm 5.2 \%$ (range: $70-85 \%, p<0.001$ ) and at $300 \mathrm{mmHg} 85.0 \pm 6.7 \%$ (range: $75-95 \%, p<0.001$ ) (Table I). The comparison of endothelial loss between each different distension pressure and baseline is shown in Figure 5.

\section{Discussion}

The saphenous vein is examined in three different layers: intima, media and adventitia. The intima is the luminal layer and it is covered with endothelia. Fenestrated basal membrane and intimal cells are adjacent to endothelial cells. The media layer is formed by longitudinal muscular cells connected with collagen and elastic fibers internally and circular muscular cells externally. The adventitia is the outermost layer of the vein wall.

In 1980, Furchgott and Zawadzki indicated that endothelium requires endothelium-derived relaxation factor (EDRF) for responding to acetylcholine; later on EDRF was renamed as nitric oxide (NO) [12]. Lately it was understood that endothelium is not just a barrier for blocking extravasation of blood cells and elements, but is also an organ with various biological functions. Endothelium takes part in regulating vascular smooth muscular cell tonus and hemostasis. Under normal circumstances, platelet activation, ad- 

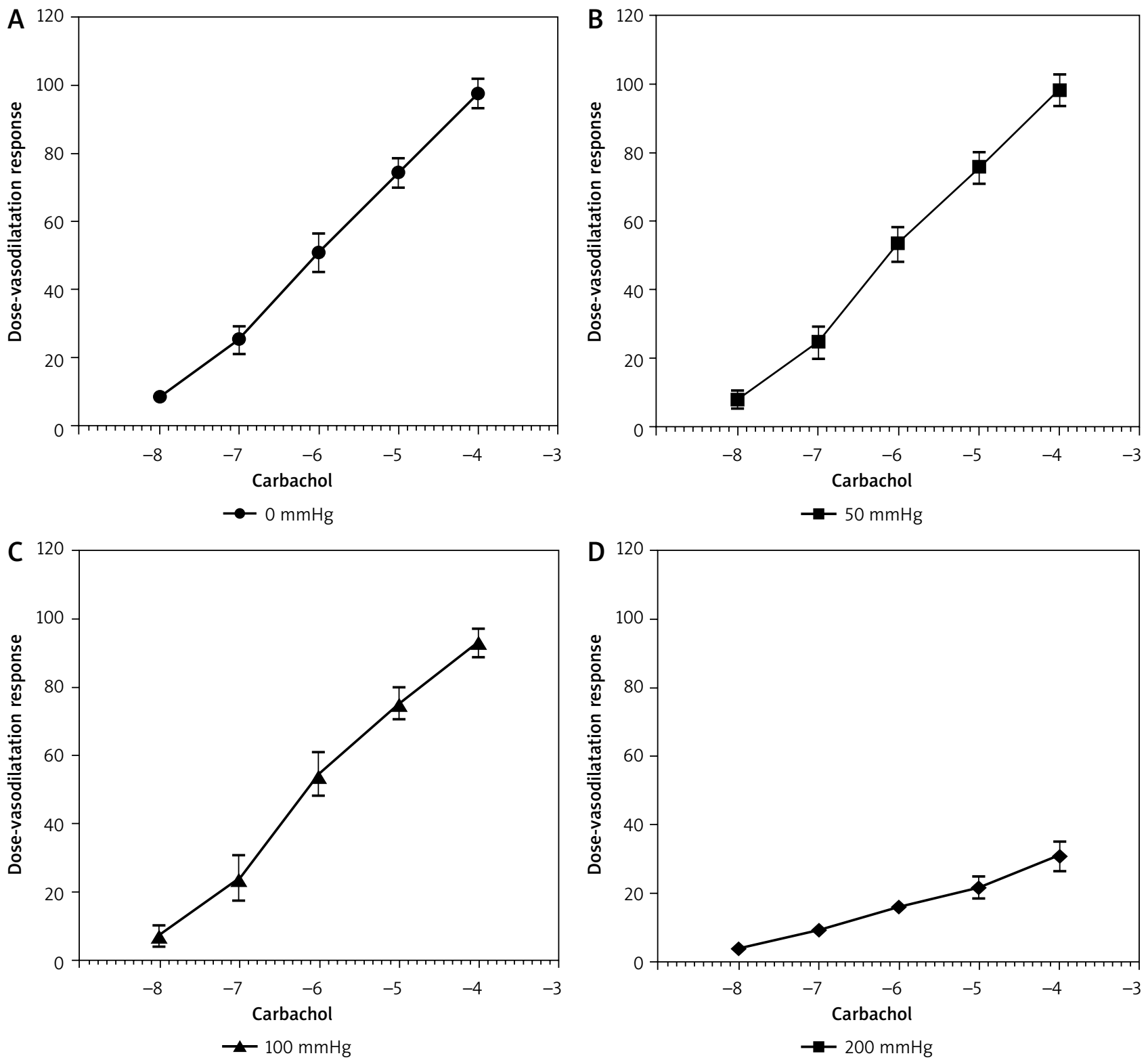

Fig. 1. Dose-vasodilatation response curves of SVGs. A) Dose-vasodilatation responses of $0 \mathrm{mmHg}$ distended SVGs, B) Dose-vasodilatation responses of $50 \mathrm{mmHg}$ distended SVGs, C) Dose-vasodilatation responses of $100 \mathrm{mmHg}$ distended SVGs, D) Dose-vasodilatation responses of $200 \mathrm{mmHg}$ distended SVGs

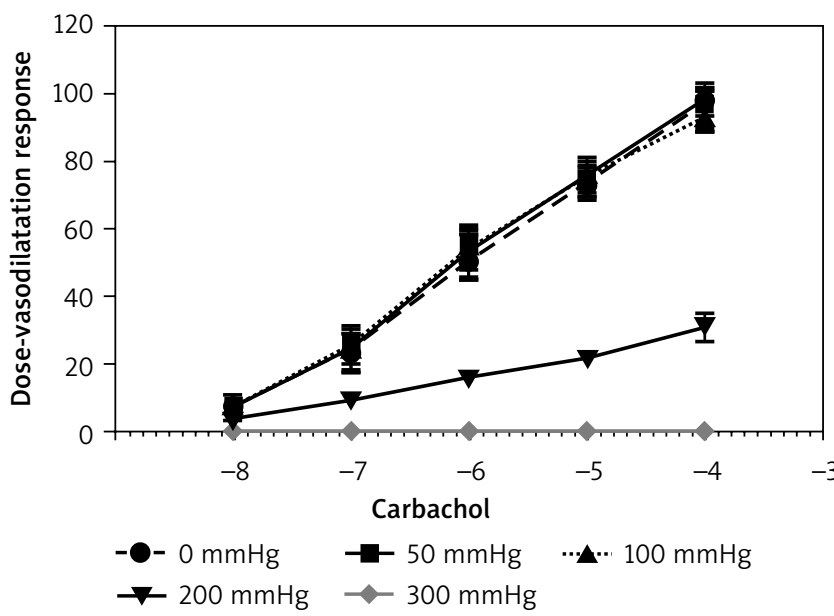

Fig. 2. Comparison of vasodilatation responses between different pressures hesion and aggregation are inhibited by prostacyclin (PGI2) and EDRF that are continuously secreted from endothelium [13]. Endothelial cells also secrete antithrombin, heparinlike substances and plasminogen activator that provide local thrombolysis [14]. Endothelial integrity of the saphenous vein graft is very important not only for its physical barrier effect but also for its ability to secrete bioactive products.

Traumatic preparation of the saphenous vein graft is considered to be responsible for early graft occlusion. High pressure applied for resolving spasm in harvesting of the graft results in endothelial detachment and media damage [15]. Lipid uptake of the vein wall is considered to be responsible for late-term patency [16]. Endothelial damage after intraluminal pressures over $150 \mathrm{mmHg}$ is blamed for reduced patency rates in many studies [17]. Galea et al. observed that apoptosis was increased in the saphenous vein 

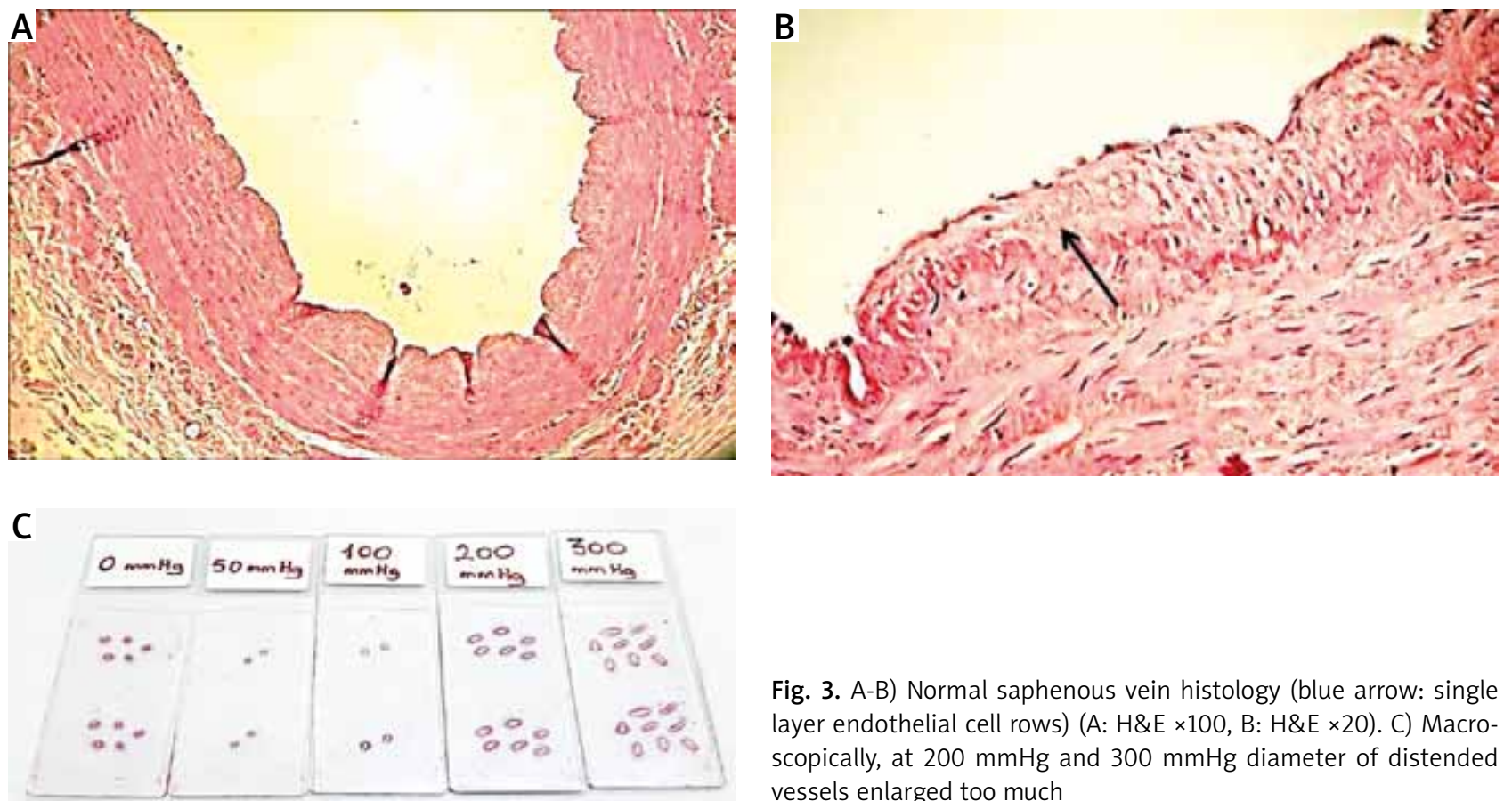

Fig. 3. A-B) Normal saphenous vein histology (blue arrow: single layer endothelial cell rows) $(\mathrm{A}: \mathrm{H} \& \mathrm{E} \times 100, \mathrm{~B}: \mathrm{H} \& \mathrm{E} \times 20)$. C) Macroscopically, at $200 \mathrm{mmHg}$ and $300 \mathrm{mmHg}$ diameter of distended vessels enlarged too much
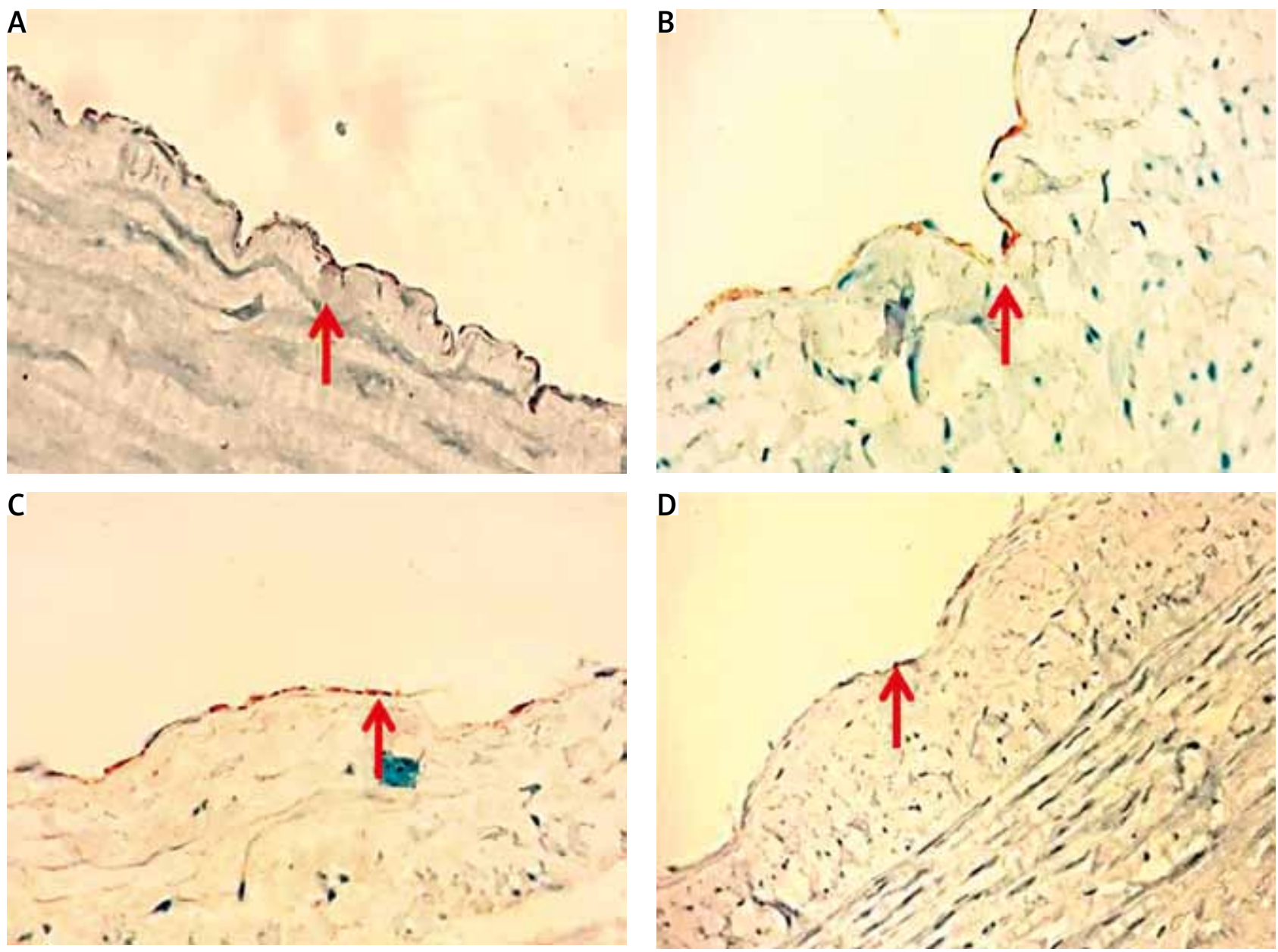

Fig. 4. Immunohistochemical CD31 staining examples of saphenous vein grafts. CD31 positive intimal endothelial cells stained in brown (red rows). A) In the baseline group ( $0 \mathrm{mmHg}$ ) saphenous veins show an almost completely intact intimal surface $(\times 20)$. B) In 50 and $100 \mathrm{mmHg}$ distension pressure groups, similarly, small de-endothelialized areas were seen ( $\times 40)$. C) In the $200 \mathrm{mmHg}$ distension pressure group, small de-endothelialized areas are more widespread ( $\times 20)$. D) A distension pressure of $300 \mathrm{mmHg}$ causes complete endothelial cell loss. Intimal surface is flattened (blue arrow) $(\times 20)$ 
Tab. I. Endothelial loss and the comparison of groups

\begin{tabular}{|c|c|c|c|c|c|c|c|}
\hline & Mean \pm SD & Med & n.-Max.) & $\begin{array}{c}\text { Change compared to } \\
0 \mathrm{mmHg} \\
\text { Mean } \pm \text { SD }\end{array}$ & $p$ & $\begin{array}{l}\text { Change compared to } \\
\text { pressure one below } \\
\text { mean } \pm \text { SD }\end{array}$ & $p$ \\
\hline $0 \mathrm{mmHg}$ & $0.8 \pm 1.6$ & 0 & $0-5$ & & & & \\
\hline $50 \mathrm{mmHg}$ & $34.5 \pm 10.8$ & 30 & $20-55$ & $33.7 \pm 10.0$ & 0.000 & & \\
\hline $100 \mathrm{mmHg}$ & $50.0 \pm 7.1$ & 50 & $40-60$ & $49.2 \pm 6.8$ & 0.000 & $15.5 \pm 12.1$ & 0.002 \\
\hline $200 \mathrm{mmHg}$ & $75.5 \pm 5.2$ & 75 & $70-85$ & $74.6 \pm 5.6$ & 0.000 & $25.5 \pm 10.1$ & 0.000 \\
\hline $300 \mathrm{mmHg}$ & $85.0 \pm 6.7$ & 85 & $75-95$ & $84.2 \pm 6.7$ & 0.000 & $9.5 \pm 8.2$ & 0.003 \\
\hline
\end{tabular}

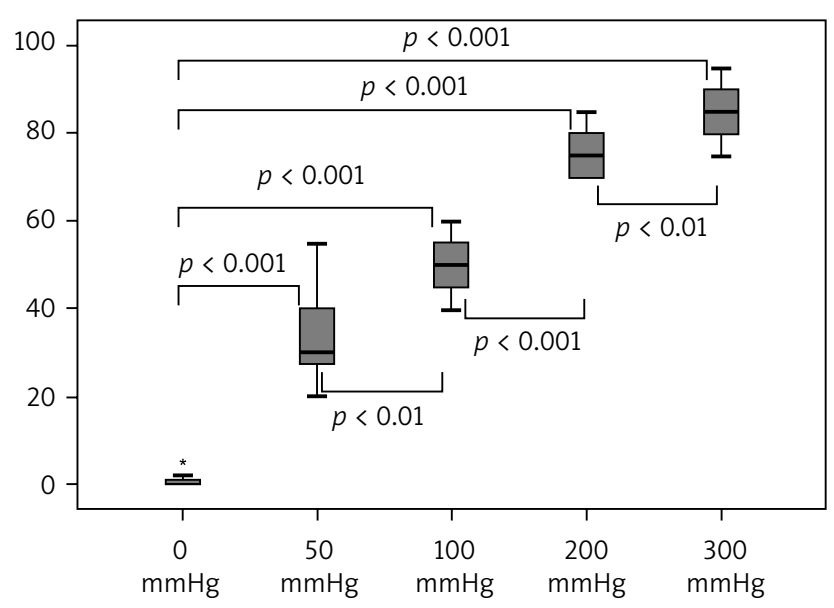

Fig. 5. Box plot diagrams of endothelial cell loss due to different distension pressures $(0,50,100,200$ and $300 \mathrm{mmHg})$. Comparison of endothelial loss between each different distended pressure and with the baseline $(0 \mathrm{mmHg})$

after distension with $350 \mathrm{mmHg}$ for two minutes [18]. Viaro et al. found that endothelial-derived nitric oxide synthase (eNOS) levels remained unchanged in SVGs distended with 100 and $200 \mathrm{mmHg}$ but were significantly lowered in SVGs distended with $300 \mathrm{mmHg}$ [10]. Similar results were obtained in studies of Chester et al. in two minutes of distension of SVGs and Dashwood et al. in one minute of distension of SVGs $[19,20]$.

Stigler et al. obtained similar results in their study. They distended SVGs to 50, 100, 150 and $300 \mathrm{mmHg}$ pressure for 30 minutes. They found that by using CD-31 immunostaining at 50, 100 and $300 \mathrm{mmHg}$ pressure, endothelial loss levels were $29 \%, 54 \%$ and $91 \%$, respectively [11].

We examined both functional and pathological changes in our study. We applied different pressures to harvested saphenous veins for two minutes and obtained similar results. Although intimal tears and endothelial loss were less in grafts distended to 0,50 and $100 \mathrm{mmHg}$, they were noticeably higher in grafts distended to 200 and $300 \mathrm{mmHg}$. Also we found that, as correlated with these pathologic findings, endothelial-derived relaxation responses were reduced in the tissue bath at grafts distended to $200 \mathrm{mmHg}$. We believe that this is caused by reduced nitric oxide activity as a result of endothelial damage due to pressure. In grafts distended with $300 \mathrm{mmHg}$, there was neither a contraction nor a relaxation response, which we believe was the result of damage not only at the endothelium but also at the media layer. We consider that pressures of $300 \mathrm{mmHg}$ or more turn the SVG into a dead pipe. There is abundant evidence suggesting that nitric oxide levels are reduced in damaged veins. Early graft vasospasm and thrombotic occlusion may be due to reduced endothelial NO levels. NO also has effects on inhibiting platelet and leukocyte adhesion, vascular smooth muscle proliferation and migration and other antioxidant effects [21].

Irrigation solution and its temperature are also effective in endothelial protection as distension pressure and time are. We preferred heparinized isotonic $0.9 \% \mathrm{NaCl}$ solution at room temperature for the irrigation solution. Bush et al. reported that the best protection is achieved at normal room temperature and $37^{\circ} \mathrm{C}$. Temperature at $4^{\circ} \mathrm{C}$ causes separation at the basal membrane and spherical changes in cells [17]. There are many reports on different irrigation solutions. In report comparing blood and isotonic $0.9 \%$ $\mathrm{NaCl}$ solution, vascular contraction and endothelial loss were greater in the group kept in blood. Vascular relaxation was better in the group kept in isotonic $0.9 \% \mathrm{NaCl}$ solution [22]. Despite reports showing that Ringer's solution or balanced electrolyte solution does less damage than isotonic $0.9 \% \mathrm{NaCl}$ solution, the least damage is achieved by heparinized blood $[17,23,24]$. We preferred isotonic $0.9 \% \mathrm{NaCl}$ solution because of the required high blood amount. As we planned to investigate the relaxation response in the tissue bath, no vasodilator agent was used before the procedure.

SVG prepared with the "no touch" technique (harvesting of graft with surrounding tissue) does not require distension. The saphenous vein is not handled neither at harvesting or while performing anastomosis and reported early patency rates are 95.4\% [25]. In our previous study, we also found that relaxation responses of SVGs harvested with the "no-touch" technique are better [9].

The main limitations of this study are that although use of a pressure infusion cuff with sphygmomanometer was preferred for distension, this pressure was not screened and blood was not used as a distension solution.

\section{Conclusions}

Examination with CD31 immunostaining revealed that endothelial damage was evident at all distension pres- 
sures, but this damage was more obvious and generalized at pressures at $100 \mathrm{mmHg}$ and over. Histologic and physiologic deformities were less in saphenous veins distended with $100 \mathrm{mmHg}$ or less but endothelial relaxation responses were obviously decreased at $200 \mathrm{mmHg}$ pressure. Especially in SVGs distended with $300 \mathrm{mmHg}$, although with endothelial and structural changes, neither vasoconstriction nor vasodilatation responses were achieved.

In conclusion, we report that distension of the SVG for coronary artery bypass grafting surgery with pressures of $100 \mathrm{mmHg}$ or less will result in less endothelial damage and increased graft patency.

\section{Funding}

The authors received no financial support for the research and/or authorship of this article.

\section{Disclosure}

The authors report no conflicts of interest.

\section{References}

1. Sabiston DC Jr. Direct surgical management of congenital and acquired lesions of the coronary circulation. Prog Cardiovasc Dis 1963; 6: 299-316.

2. Favaloro RG. Saphenous vein graft in the surgical treatment of coronary artery disease: operative technique. J Thorac Cardiovasc Surg 1969; 58: 178-185.

3. Barner HB, Standeven JW, Reese J. Twelve-year experience with internal mammary artery for coronary artery bypass. J Thorac Cardiovasc Surg 1985; 90: 668-675.

4. Loop FD, Lytle BW, Cosgrove DM, Stewart RW, Goormastic M, Williams GW Golding LAR, Gill CC, Taylor PC, Sheldon WC, Proudfit WL. Influence of the internal-mammary-artery graft on 10-year survival and other cardiac events. N Engl J Med 1986; 314: 1-6.

5. Bourassa MG, Campeau L, Lesperance J, Grondin CM. Changes in grafts and coronary arteries after saphenous vein aortocoronary bypass surgery: results at repeat angiography. Circulation 1982; 65 (Suppl 2): 90-97.

6. Grondin CM, Campeau L, Lesperance J, Enjalbert M, Bourassa MG. Comparison of late changes in internal mammary artery and saphenous vein grafts in two consecutive series of patients 10 years after operation. Circulation 1984; 70 (Suppl 1): I208-212.

7. Ramos JR, Berger K, Mansfield PB, Sauvage LR. Histologic fate and endothelial changes of distended and non distended vein grafts. Ann Surg 1976; 183: 205-228.

8. Dashwood MR, Tsui JC. 'No-touch' saphenous vein harvesting improves graft performance in patients undergoing coronary artery bypass surgery: a journey from bedside to bench.Vascul Pharmacol 2013; 58: 240-250.

9. Gur O, Gurkan S, Gur DO, Karadag H, Ege T. Comparison of vasospasm and vasodilatation response of saphenous vein grafts harvested by conventional and no-touch techniques. Turkish J Thorac Cardiovasc Surg 2012; 20: 510-514.
10. Viaro F, Capellini VK, Celotto AC, Carlotti CG Jr, Rodriques AJ, Reis GS, Augusto VS, Evora PR. Immunohistochemical evaluation of three nitric oxide synthase isoforms in human saphenous vein exposed to different degrees of distension pressures. Cardiovasc Pathol 2010; 16: 211-220.

11. Stigler R, Steger C, Schachner T, Holfeld J, Edlinger M, Grimm M, Semsroth $\mathrm{S}$. The impact of distension pressure on acute endothelial cell loss and neointimal proliferation in saphenous vein grafts. Eur J Cardiothorac Surg 2012; 42: 74-79.

12. Furchgott RF, Zawadzki JV. The obligatory role of endothelial cells in the relaxation of arterial smooth muscle by acetylcholine. Nature 1980; 288: 373-376.

13. Furchgott RF. Endothelium-derived relaxing factor: discovery, early studies, and identification as nitric oxide. Biosci Rep 1999; 19: 235-251.

14. Chan V, Chan TK. Antithrombin III in fresh and cultured human endothelial cells: a natural anticoagulant from the vascular endothelium. Thromb Res 1979; 15: 209-213.

15. Angelini GD, Passani SL, Breckenridge IM, Newby AC. Nature and pressure dependence of damage induced by distension of human saphenous vein coronary artery bypass grafts. Cardiovasc Res 1987; 21: 902-907.

16. Hata M, Takayama T, Sezai A, Yoshitake I, Hirayama A, Minami K. Efficacy of aggressive lipid controlling therapy for preventing saphenous vein graft disease. Ann Thorac Surg 2009; 88: 1440-1444.

17. Bush HL Jr, McCabe ME, Nabseth DC. Functional injury of vein graft endothelium. Role of hypothermia and distention. Arch Surg 1984; 119: 770-774.

18. Galea J, Armstrong J, Francis SE, Cooper G, Crossman DC, Holt CM. Alterations in c-fos expression, cell proliferation and apoptosis in pressure distended human saphenous vein. Cardiovasc Res 1999; 44: 436-448.

19. Chester AH, Buttery LD, Borland JA, Springall DR, Rothery S, Severs NJ, Polak JM, Yacoub MH. Structural, biochemical and functional effects of distending pressure in the human saphenous vein: implication for bypass grafting. Coron Artery Dis 1998; 9: 143-151.

20. Dashwood MR, Savage K, Tsui JC, Dooley A, Shaw SG, Fernandez Alfonso MS, Bodin L, Souza DS. Retaining perivascular tissue of human saphenous vein grafts protects against surgical and distension-induced damage and preserves endothelial nitric oxide synthase and nitric oxide synthase activity. J Thorac Cardiovasc Surg 2009; 138: 334-340.

21. Sogo N, Campanella C, Webb DJ, Megson IL. S-nitrosothiols cause prolonged, nitric oxide-mediated relaxation in saphenous vein and internal mammary artery: therapeutic potential in bypass surgery. Br J Pharmacol 2000; 131: 1236-1244.

22. Haudenschild C, Gould KE, Quist WC, LoGerfo FW. Protection of endothelium in vessel segments excised for grafting. Circulation 1981; 64: ॥101-107.

23. Wilbring M, Tugtekin SM, Zatschler B, Ebner A, Reichenspurner H, Matschle K, Deussen A. Even short-time storage in physiological saline solution impairs endothelial vascular function of saphenous vein grats. Eur J Cardiothorac Surg 2011; 40: 811-815.

24. Wilbring M, Ebner A, Schoenemann K, Knaut M, Tugtekin SM, Zatschler B, Waldow T, Alexiou K, Matschke K, Deussen A. Heparinized blood better preserves cellular energy charge and vascular functions of intraoperatively stored saphenous vein grafts in comparison to isotonic sodium-chloridesolution. Clin Hemorheol Microcirc 2013; 55: 445-455.

25. Souza DS, Bomfim V, Skoglund H, Dashwood MR, Boroweic JW, Bodin L, Filbey D. High early patency of saphenous vein graft for coronary artery bypass harvested with surrounding tissue. Ann Thorac Surg 2001; 71: 797-800. 